\title{
PENGARUH LINGKUNGAN KELUARGA, EFIKASI DIRI DAN PRESTASI BELAJAR EKONOMI TERHADAP PERILAKU ANTI KORUPSI
}

\author{
Eko Siam Muwardi \& Ali Muhson \\ Universitas Negeri Yogyakarta, Indonesia \\ Siameko88@gmail.com, alimuhson@uny.ac.id
}

\begin{abstract}
Abstrak: Penelitian ini bertujuan untuk mengetahui pengaruh lingkungan keluarga terhadap efikasi diri, pengaruh lingkungan keluarga terhadap prestasi belajar ekonomi, pengaruh efikasi diri terhadap prestasi belajar ekonomi, pengaruh efikasi diri terhadap perilaku anti korupsi, pengaruh prestasi belajar ekonomi terhadap perilaku anti korupsi dan pengaruh lingkungan keluarga terhadap perilaku anti korupsi pada siswa SMAN 1 Karanganyar Kabupaten Kebumen. Penelitian ini merupakan penelitian ex-post facto dengan menggunakan pendekatan kuantitatif teknik analisis jalur (path analisis). Hasil penelitian menunjukkan bahwa; Lingkungan keluarga berpengaruh positif dan signifikan terhadap efikasi diri. Lingkungan keluarga tidak berpengaruh positif dan signifikan terhadap prestasi belajar ekonomi. Efikasi diri tidak berpengaruh positif dan signifikan terhadap prestasi belajar ekonomi. Efikasi diri berpengaruh positif dan signifikan terhadap perilaku anti korupsi. Prestasi belajar ekonomi tidak berpengaruh positif dan signifikan terhadap perilaku anti korupsi. Lingkungan keluarga tidak berpengaruh positif dan signifikan terhadap perilaku anti korupsi.

Kata kunci: Lingkungan Keluarga, Efikasi Diri, Prestasi Belajar Ekonomi dan Perilaku anti Korupsi
\end{abstract}

\section{THE EFFECT OF ENVIRONMENTAL FAMILY, SELF-EFICATION AND ECONOMIC LEARNING ACHIEVEMENT USING ANTI-CORRUPTION BEHAVIOR}

\begin{abstract}
This study aims to find out: the effect of the family environment on the selfefficacy, the effect of the family environment on the economics learning achievement, the effect of the self-efficacy on the economics learning achievement, the effect of the selfefficacy on the anti-corruption behavior, the effect of the economics learning achievement on the anti-corruption behavior, and the effect of the family environment on the anticorruption behavior among students of SMAN 1 Karanganyar, Kebumen Regency. This was an ex post facto study using the quantitative approach. The data were collected using questionnaires and documentation and were analyzed using the path analysis technique. The results of the study are as follows. The family environment variable has a significant positive effect on the self-efficacy. The family environment variable does not have an effect on the economics learning achievement. The self-efficacy variable does not have an effect on the economics learning achievement. The self-efficacy variable has a significant positive effect on the anti-corruption behavior. The economics learning achievement does not have an effect on the anti-corruption behavior. The family environment variable has a significant positive effect on the anti-corruption behavior.
\end{abstract}

Keywords: Family Environment, Self-efficacy, Economics Learning Achievement, Anticorruption Behavior

\section{PENDAHULUAN}

Kasus korupsi di Indonesia akhir - akhir ini masih banyak terjadi. Masih banyaknya tindakan korupsi di negeri ini ditandai dengan makin meningkatnya kasus - kasus yang ditangani oleh KPK. Berdasarkan data statistik yang dimuat pada acch.kpk.go.id, Per 30 November 2017, di tahun 2017 KPK telah melakukan penanganan tindak pidana korupsi dengan jumlah yang 
banyak. Adapun rincian kasus yang ditangani KPK adalah penyelidikan sebanyak 114 perkara, penyidikan sebanyak 118 perkara, kemudian untuk penuntutan sebanyak 94 perkara, inkracht sebanyak 73 perkara, dan eksekusi 76 perkara (https://acch.kpk.go.id/id, 2017). Angka tersebut memiliki kecenderungan naik dari tahun ke tahun. Jumlah kasus tersebut disinyalir semakin banyak karena belum termasuk angka dari kejaksaan dan kepolisian.

Banyak kasus korupsi hampir terjadi disegala lini, dari tingkat desa sampai tingkat pusat dan menjerat berbagai pihak mulai pihak swasta, ASN, DPRD, kepala daerah hingga menteri. Salah satu kabupaten yang tersandung kasus korupsi adalah Kabupaten Kebumen. Banyaknya kasus korupsi yang terjadi di Indonesia khususnya yang terjadi di Kebumen bertolak belakang dengan survei yang dilakukan oleh BPS berkaitan dengan Indeks Perilaku Anti Korupsi (PAK). Angka IPAK terus naik dari tahun 2012 sebesar 3,55\%, 2013 sebesar 3,63\%, tahun 2014 sebesar 3,61\%, 2015 sebesar 3,59\% dan tahun 2017 sebesar 3,71\%. Seharunya dengan IPAK yang semakin tinggi kasus korupsi di Indonesia khususnya kebumen semakin rendah, namun nyatanya kasus korupsi semakin banyak jumlahnya.

Penanaman perilaku anti korupsi hendaknya dilakukan sejak dini khususnya di Kabupaten Kebumen. Penanaman perilaku anti korupsi ini hendaknya pada pelajar terutama pada jenjang SMA sebagai generasi penerus bangsa. Penanaman perilaku anti korupsi pada siswa ini hendaknya dimulai sejak lingkungan keluarga, yang didukung dengan meningkatkan sifat efikasi diri siswa. Perilaku anti korupsi juga harus bisa ditanamkan melalui sekolah dengan meningkatkan prestasi belajar siswa khususnya prestasi belajar ekonominya.

Perilaku anti korupsi adalah perilaku yang menjunjung tinggi nilai - nilai anti korupsi. Nilai nilai anti korupsi merupakan nilai yang disisipkan dalam kegiatan pembelajaran sebagai upaya pencegahan korupsi hasil dari kerja sama KPK dengan Kemendiknas pada tahun 2011. Nilai nilai anti korupsi memiliki sembilan nilai, namun pada penelitian ini fokus pada empat nilai yakni kejujuran, disiplin, tanggungjawab dan sederhana.

Pembentukan perilaku anti korupsi pada siswa sejatinya sangat dipengaruhi oleh lingkungan keluarganya. Lingkungan keluarga merupakan lingkungan yang terdiri dari anggota keluarga, suasana dan segala sesuatu yang ada pada rumah tangga yang ditempati oleh siswa. Fungsi keluarga salah satunya adalah fungsi pendidikan dimana keluarga akan menanamkan nilai, norma karakter dan perilaku kepada seorang anak (Aziz, 2015:17). Perilaku korup dapat terjadi karena dorongan keluarga, oleh karena itu lingkungan keluarga yang baik akan meningkatkan perilaku anti korupsi seseorang (Kemendikbud, 2011:48). Selain itu pendidikan karakter pada keluraga juga berpengaruh terhadap perilaku anti korupsi pada remaja, khususnya siswa SMA (Utami, Hasanah\&Tarma, 2016).

Lingkungan keluarga dalam membentu perilaku anti korupsi juga dapat melalui efikasi diri. Efikasi diri merupakan sebuah penilaian seorang indivdu terhadap kemampuan yang ada dalam diri individu tersebut, untuk melakukan perilaku atau mencapai tujuan tertentu (Ormrod, 2008:20). Salah satu fungsi keluarga adalah fungsi psikologis yakni membentuk karakter kejiwaan seseorang termasuk percaya terhadap kemampuan yang dimilikinya atau efikasi diri (Aziz, 2015:17). Sehingga lingkungan keluarga berpengaruh terhadap efikasi diri seseorang. Dukungan sosial keluarga siswa berpengaruh terhadap efikaasi dirinya (Widanarti\&Indati, 2002).

Efikasi diri yang terdapat dalam diri seorang individu dapat mepengaruhi perilaku dan kognisinya. (Ormrod,2008: 21-23). Perilaku seseorang yang dibentuk oleh efikasi diri salah satunya adalah perilaku anti korupsi. Efikasi diri berpengaruh secara negatif dan signifikan terhadap perilaku mencontek siswa ( Purwanto, 2014). Semakin tinggi tingkat efikasi diri yang dimiliki siswa maka akan semakin rendah perilaku menconteknya. Siswa yang memiliki efikasi 
diri yang tinggi akan cenderung untuk berperilaku baik, seperti tidak mencontek demi menjunjung kejujuranya. Dengan demikian efikasi diri berpengaruh terhadap perilaku anti korupsi, dimana dalam perilaku anti korupsi salah satu indikatornya adalah kejujuran. Efikasi diri dalam penelitian ini diukur dari ingkat kesulitas (level), generaliasi (generality) dan tingkat kekuatan (strength) (Bandura, 1997:42-43).

Perilaku anti korupsi yang dibentuk oleh lingkungan keluarga juga dapat melalui prestasi belajar ekonomi. Prestasi belajar ekonomi merupakan sebuah nilai yang diperoleh siswa setelah menempuh pembelajaran ekonomi. Tujuan pembelajaran ekonomi sesuai dengan tujuan kurikulum 2013 yang mana mencakup kompetesi sikap spiritual, sikap sosial, pengetahuan dan keterampilan (Lampiran 12 Permendikbud No 24, 2016:1). Tujuan mpembelajaran tersebut selain membentuk siswa paham akan konsep dan dapat menjadi mahluk ekonomi yang baik, juga mampu menjunjung nilai karakter termasuk nilai - nilai anti korupsi. Semakin tinggi prestasi belajar siswa semakin baik perilaku konsumsinya (Purwanti, 2011). Perilaku konsumsi yang baik mencerminkan sifat sederhana, sehingga prestasi belajar ekonomi berpengaruh positif terhadap perilaku anti korupsi.

Prestasi belajar ekonomi juga dapat dipengaruhi oleh efikasi diri. Efikasi diri yang dimiliki oleh seseorang dapat mepengaruhi perilaku dan kognisinya. Perilaku dan kognisi yang dipengaruhi oleh efikasi diri adalah salah satunya adalah pembelajaran dan prestasi seseorang termasu prestasi beajar ekonomi (Ormrod, 2008: 21-23). Semakin tinggi efikasi diri yang dimiliki oleh siswa, maka akan semakin tinggi pula prestasi yang diraihnya ( Haris, 2016).

Prestasi belajar ekonomi juga dapat dipengaruhi oleh lingkungan keluarga. Lingkungan keluarga yang baik dan kondusif dapat meningkatkan prestasi belajar ekonomi siswa. Indikator yang mempengaruhi prestasi belajar ekonomi dalam penelitian ini adalah teladan orang tua, relasi antar anggota keluarga, keadaan ekonomi keluarga dan perhatian orang tua (Slameto, 2015:6064). Hal tersebut juga sejalan dengan penelitian yang dilakukan oleh Yana\&Nurjanah (2014) yang menyatakan bahwa lingkungan keluarga berpengaruh positif terhadap prestasi belajar ekonomi siswa.

Tujuan dalam penelitian ini adalah untuk mengetahui pengaruh lingkungan keluarga terhadap efikasi diri, pengaruh lingkungan keluarga terhadap prestasi belajar ekonomi, pengaruh efikasi diri terhadap prestasi belajar ekonomi, pengaruh efikasi diri terhadap perilaku anti korupsi, pengaruh prestasi belajar ekonomi terhadap perilaku anti korupsi dan pengaruh lingkungan keluarga terhadap perilaku anti korupsi.

\section{METODE}

Penelitian ini adalah penelitian ex post facto dengan menggunakan pendekatan kuantitatif. Penelitian ini menggunakan Lingkungan Keluarga sebagai variabel endogen (X1), dan variabel eksogennya antara lain Efikasi Diri (Y1), Prestasi Belajar Ekonomi (Y2) dan Perilaku Anti Korupsi (Y3). Penelitian ini menggunakan pendekatan analisis jalur (Path Analisis). Penelitian ini dilaksanakan di SMAN 1 Karanganyar Kabupaten Kebumen yang beralamat di Jalan Kemakmuran No. 51 Karanganyar Kebumen. Waktu penelitian akan dilaksanakan pada tanggal 10 Agustus 2018 sampai tanggal 10 September 2018.

Populasi dan sampel berjumlah 130 siswa yang terdapat pada kelas XI IIS, pengambilan data menggunakan teknik sensus. Dikarenakan ada 5 data yang outlier maka data yang digunakan dalam penelitian sebanyak 125 . Penelitian ini menggunakan data primer dan data sekunder.

Data primer digunakan pada variabel lingkungan keluarga, efikasi diri dan perilaku anti korupsi. Variabel lingkungan keluarga mengukur keteladanan, relasi antar anggota keluarga, 
keadaan ekonomi keluarga dan perhatian orang tua. Efikasi diri mengukur tentang tingkat kesulitan (level), generalitas (generality) dan tingkat kekuatan (strength). Variabel lingkungan keluarga dan efikasi diri diukur dengan angket skala likert lima poin alternatif jawaban dari sangat sering sampai tidak pernah. Khusus untuk perilaku anti korupsi menggunakan pertanyaan situasional judgement test dimana pertanyaan diseting seperti kasus nyata dengan alternatif jawaban yang bernilai 1 sampai 3. Variabel perilaku anti korupsi digunakan untuk mengukur nilai - nilai anti korupsi seperti kejujuran, disiplin, tanggungjawab dan sederhana.

Analisis data dalam penelitian ini menggunakan analisis jalur (path analysis) yang berfungsi untuk mengetahui pengaruh variabel eksogen terhadap endogen baik secara langsung maupun tidak langsung. Sebelum melakukan uji dengan analisis jalur langkah yang dilakukan terlebih dahulu yakni melakukan uji prasyarat analisis yang terdiri dari uji normalitas, linearitas dan multikolinearitas.

\section{HASIL DAN PEMBAHASAN}

Hasil penelitian yang dilakukan menghasilkan kecenderungan variabel, adapun kecenderungan variabel perilaku anti korupsi adalah sebagai berikut:

Tabel 1. Kecenderungan Variabel Perilaku Anti Korupsi

\begin{tabular}{llccc}
\hline No & Kategori & Frekuensi & Persentase & Keterangan \\
\hline $\mathbf{1}$ & $X>57,5$ & 66 & 52.8 & Sangat Baik \\
$\mathbf{2}$ & $49,83<=X<57,5$ & 48 & 38.4 & Baik \\
$\mathbf{3}$ & $42,17<=X<49,83$ & 10 & 8 & Sedang \\
$\mathbf{4}$ & $34,5<=X<42,17$ & 1 & 0.8 & Kurang \\
$\mathbf{5}$ & $X<34,5$ & 0 & 0 & Sangat Kurang \\
\hline & Jumlah & 125 & 100 & \\
\hline
\end{tabular}

Berdasarkan tabel 1 tersebut, kecenderungan variabel perilaku anti korupsi berada pada kategori sangat baik dengan nilai 52,8\% dengan frekuensi sebanyak 66 responden. Kecenderungan variabel perilaku anti korupsi yang berada pada posisi sangat baik mengindikasikan bahwa siswa cenderung menjunjung tinggi nilai - nilai anti korupsi yakni kejujuran, disiplin, tanggungjawab dan sederhana. Kecenderungan variabel prestasi belajar ekonomi siswa berada pada kategori cukup yakni sebesar $68,8 \%$ dengan frekuensi sebanyak 86 responden. Kecenderungan variabel efikasi diri terdapat pada kategori tinggi sebesar 50,4\% dengan frekuensi sebanyak 63 responden. Kecenderungan variabel lingkungan keluarga berada pada kategori sangat baik sebesar $66,4 \%$ dengan frekuensi sebanyak 83 responden.

Uji normalitas mengunakan nilai critical ratio pada multivariate. Nilai c.r. dalam penelitian ini sebesar 0,647 dengan syarat c.r. multivariate antara -1,96,c.r.1,96 maka data dalam penelitian ini berdistribusi normal.

Uji linieritas pada penelitian ini yakni variabel lingkungan keluarga terhadap efikasi diri memiliki nilai sig. F sebesar 0,139. Variabel lingkungan keluarga terhadap prestasi belajar ekonomi memiliki nilai sig. F sebesar 0,101. Variabel efikasi diri terhadap prestasi belajar ekonomi memiliki nilai sig. F sebesar 0,870 . Variabel efikasi diri terhadap perilaku anti korupsi memiliki nilai sig. F sebesar 0,747. Variabel prestasi belajar ekonomi terhadap perilaku anti korupsi memiliki nilai sig. F sebesar 0,307 . Variabel lingkungan keluarga terhadap perilaku anti korupsi 
memiliki nilai sig. F sebesar 0,736 . Berdasarkan hasil tersebut, maka semua hubungan antara variabel bersifat linier.

Uji multikolinieritas digunakan uji VIF (Variance Inflation Factor). Hasil uji multikolinearitas dengan variabel terikat adalah perilaku anti korupsi yakni lingkungan keluarga memiliki nilai VIF sebesar 1,148, efikasi diri memiliki nilai VIF sebesar 1,144 dan prestasi belajar ekonomi memiliki nilai VIF sebesar 1,007. Bersarkan hasil tersebut maka dapat disimpulkan semua variabel tidak terjadi multikolinearitas.

Tabel 2. Uji Hipotesis.

\begin{tabular}{cccccc}
\hline Variabel & $\begin{array}{c}\text { Standardized } \\
\text { Regression } \\
\text { Weights }\end{array}$ & Estimate & S.E. & C.R. & $P$ (1- tailed) \\
\hline LK terhadap ED & 0,352 & 0,333 & 0,080 & 4,183 & ${ }^{* \star \star *}$ \\
LK terhadap PB & 0,082 & 0,050 & 0,059 & 0,857 & 0,1955 \\
ED terhadap PB & $-0,057$ & $-0,037$ & 0,062 & $-0,597$ & 0,2755 \\
ED terhadap PA & 0,198 & 0,212 & 0,097 & 2,179 & 0,0145 \\
PB terhadap PA & 0,077 & 0,127 & 0,141 & 0,900 & 0,184 \\
LK terhadap PA & 0,187 & 0,189 & 0,092 & 2,052 & 0,02 \\
\hline
\end{tabular}

Berdasarkan tabel 2 menunjukkan bahwa lingkungan keluarga terhadap efikasi diri memiliki nilai Standardized Regression Weights sebesar 0,352 dan nilai C.R. sebesar 4,183 serta nilai P kurang dari $0,001(\mathrm{P}<0,001)$. Berdasarkan hasil tersebut, membuktikan bahwa lingkungan keluarga berpengaruh secara positif dan signifikan terhadap efikasi diri. Semakin baik lingkungan keluarga semakin tinggi efikasi dirinya begitu pula sebaliknya. Hasil tersebut sejalan dengan pendapat Aziz (2015:17) dimana salah satu Salah satu fungsi keluarga adalah fungsi psikologis yakni membentuk karakter kejiwaan seseorang termasuk percaya terhadap kemampuan yang dimilikinya atau efikasi diri. Sehingga lingkungan keluarga berpengaruh terhadap efikasi diri seseorang. Hasil penelitian ini juga menguatkan penelitian terdahulu yang dilakukan oleh Widanarti\&Indati (2002) yang membuktikan bahwa dukungan sosial keluarga siswa berpengaruh terhadap efikaasi dirinya.

Lingkungan keluarga terhdap prestasi belajar ekonomi memiliki nilai Standardized Regression Weights sebesar 0,082 dan nilai C.R. sebesar 0,857 serta nilai P sebesar 0,1955 atau lebih dari 0,05 $(\mathrm{P}>0,05)$. Berdasarkan hasil tersebut, maka lingkungan keluarga tidak bepengaruh terhadap prestasi belajar ekonomi. Hal ini bertolak belakang dengan teori yang dikemukaan oleh Slameto (2015:60-64) prestasi belajar dipengaruhi oleh lingkungan keluarga. Hasil penelitian ini juga tidak sejalan dengan penelitian terdahulu yang dilakukan oleh Yana\&Nurjanah (2014) yang menyatakan bahwa lingkungan keluarga berpengaruh positif terhadap prestasi belajar ekonomi siswa.

Efikasi diri terhadap prestasi belajar ekonomi menunjukan nilai Standardized Regression Weights sebesar -0,057 dan nilai C.R. sebesar -0,597 serta nilai $P$ sebesar 0,2755 atau lebih dari 0,05 $(\mathrm{P}>0,05)$. Berdasarkan hasil tersebut, maka efikasi diri tidak berpengaruh terhadap prestasi belajar ekonomi. Hasil penelitian ini tidak sejalan dengan teori yang dikemukakan oleh Ormrod (2008:2123) yang menyatakan bahwa efikasi diri berpengaruh terhadap perilaku dan kognisi seseorang, dimana salah satu aspek dalam perilaku dan kognisi seseorang yang dipengaruhi adalah pembelajaran dan prestasi termasuk prestasi belajar ekonomi. Hasil penelitian ini juga tidak 
sejalan dengan penelitian terdahulu yang dilakukan oleh Haris (2016) yang membuktikan terdapat pengaruh efikasi diri terhadap prestasi belajar.

Efikasi diri terhadap perilaku anti korupsi menunjukan nilai Standardized Regression Weights sebesar 0,198 dan nilai C.R. sebesar 2,179 serta nilai P sebesar 0,0145 atau kurang dari 0,05 $(\mathrm{P}<0,05)$. Berdasarkan hasil tersebut, maka efikasi diri berpengaruh positif dan signifikan terhadap perilaku anti korupsi. Artinya semakin tinggi efikasi diri yang dimiliki oleh siswa tersebut, semakin baik pula perilaku anti korupsi yang dimiliki oleh siswa tersebut. Hasil penelitian ini sejaan dengan teori yang dikemukakan oleh Ormrod (2008:21-23) yang menyatakan bahwa efikasi diri yang dimiliki oleh seseorang dapat mepengaruhi perilaku dan kognisinya, termasuk perilaku anti korupsinya. Hasil penelitian ini juga sejalan dengan penelitian terdahulu yakni penelitian yang dilakukan oleh Purwanto (2014) yang membuktikan bahwa efikasi diri berpengaruh secara negatif dan signifikan terhadap perilaku mencontek siswa. Semakin tinggi tingkat efikasi diri yang dimiliki siswa tersebut, maka akan semakin rendah perilaku menconteknya. Sehingga siswa yang memiliki efikasi diri tinggi senantiasa menjaga perilakunya termasuk perilaku jujur, hal ini berarti efikasi diri mampu mempengaruhi perilaku anti korupsi, karena sejatinya perilaku anti korupsi berkaitan dengan kejujuran.

Prestasi belajar ekonomi terhadap perilaku anti korupsi menunjukan nilai Standardized Regression Weights sebesar 0,077 dan nilai C.R. sebesar 0,900 serta nilai P sebesar 0,184 atau lebih dari 0,05 $(\mathrm{P}>0,05)$. Berdasarkan hasil tersebut, maka prestasi belajar ekonomi tidak berpengaruh terhadap perilaku anti korupsi. Hasil penelitian ini tidak sejalan dengan tujuan pembelajaran ekonomi kurikulum 2013 yang mana mencakup kompetesi sikap spiritual, sikap sosial, pengetahuan dan keterampilan (Lampiran 12 Permendikbud No 24, 2016:1). Tujuan pembelajaran tersebut selain membentuk siswa paham akan konsep dan dapat menjadi mahluk ekonomi yang baik, juga mampu menjunjung nilai karakter termasuk nilai - nilai anti korupsi. Hasil Penelitian ini juga bertolak belakang dengan penelitian terdahulu yang dilakukan oleh Purwanti (2011) yang membuktikan bahwa Prestasi belajar ekonomi siswa berpengaruh positif dan signifikan terhadap perilaku konsumsi. Semakin tinggi prestasi belajar siswa semakin baik dan selektif perilaku konsumsinya. Perilaku konsumsi yang baik mencerminkan sifat sederhana, sehingga prestasi belajar ekonomi berpengaruh positif terhadap perilaku anti korupsi.

Lingkungan keluarga terhdap perilaku anti korupsi menunjukan nilai Standardized Regression Weights sebesar 0,187 dan nilai C.R. sebesar 2,052 serta nilai $\mathrm{P}$ sebesar 0,02 atau kurang dari 0,05 $(\mathrm{P}<0,05)$. Berdasarkan hasil tersebut, maka lingkungan keluarga berpengaruh positif dan signifikan terhadap perilaku anti korupsi. Artinya, semakin baik lingkungan keluarga, semakin baik pula perilaku anti korupsinya. Hasil penelitian ini sejalan dengan teori yang dikemukakan oleh Aziz (2015:17) dimana fungsi keluarga salah satunya adalah fungsi pendidikan dimana keluarga akan menanamkan nilai, norma karakter dan perilaku kepada seorang anak. Selain itu hasil penelitian ini juga sejalan dengan teori yang dikemukakan oleh Kemendikbud (2011) yang menyatakan bahwa perilaku korup dapat terjadi karena dorongan keluarga, oleh karena itu lingkungan keluarga yang baik akan meningkatkan perilaku anti korupsi seseorang. Hasil penelitian ini juga menguatkan penelitian terdahulu yang dilakukan oleh Utami, Hasanah\&Tarma (2016) yang menyatakan bahwa terdapat pengaruh positif dan signifikan pendidikan karakter anti korupsi pada keluarga terhadap karakter anti korupsi pada remaja. 


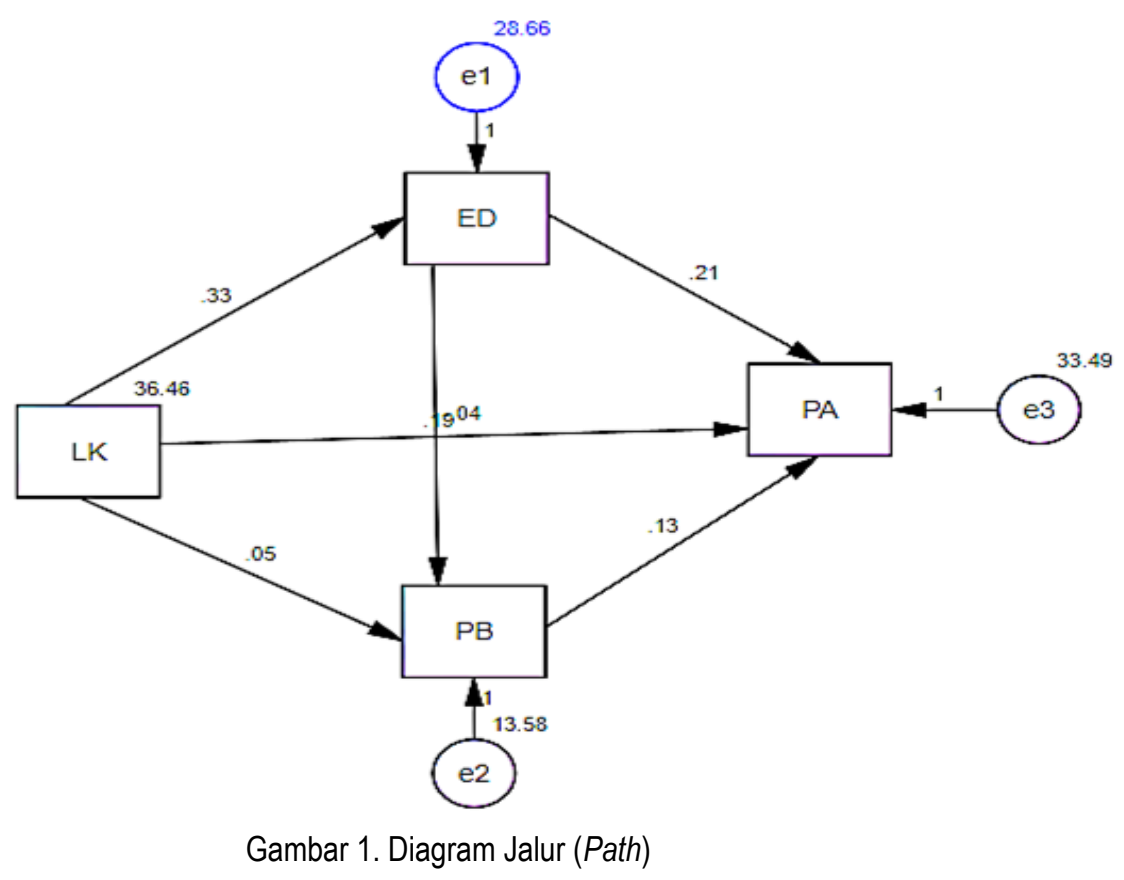

Berdasarkan hasil uji hipotesis dan gambar 1 di atas, dapat disimpulkan bahwa; Analisis jalur pertama terdapat pengaruh langsung lingkungan keluarga terhadap perilaku anti korupsi, dan terdapat pengaruh tidak langsung antara lingkungan keluarga dengan perilaku anti korupsi melalui efikasi diri. Besarnya pengaruh langsung sebesar 0,187 besarnya pengaruh tidak langsung sebesar 0,074 dan besarnya pengaruh total sebesar 0,261. Analisis jalur yang kedua terdapat pengaruh langsung lingkungan keluarga terhadap perilaku anti korupsi, namun tidak terdapat pengaruh tidak langsung lingkungan keluarga terhadap perilaku anti korupsi melalui efikasi diri dan prestasi belajar ekonomi. Analisis jalur yang ketiga Analisis jalur yang kedua terdapat pengaruh langsung lingkungan keluarga terhadap perilaku anti korupsi, namun tidak terdapat pengaruh tidak langsung lingkungan keluarga terhadap perilaku anti korupsi melalui prestasi belajar ekonomi.

\section{SIMPULAN}

Berdasarkan data yang diperoleh dari hasil analisis yang dilakukan maka dapat ditarik kesimpulan sebagai berikut: 1) Terdapat pengaruh positif dan signifikan lingkungan keluarga terhadap efikasi diri dengan nilai Standardized Regression Weights sebesar 0,35 dan nilai C.R. sebesar 4,183 serta nilai $\mathrm{P}$ kurang dari $0,001(\mathrm{P}<0,001)$; 2) Tidak terdapat pengaruh lingkungan keluarga terhadap prestasi belajar ekonomi; 3) Tidak terdapat pengaruh efikasi diri terhadap prestasi belajar ekonomi; 4) Terdapat pengaruh positif dan signifikan efikasi diri terhadap perilaku anti korupsi dengan nilai Standardized Regression Weights sebesar 0,198 dan nilai C.R. sebesar 2,179 serta nilai P sebesar 0,0145 atau kurang dari $0,05(\mathrm{P}<0,05)$; 5) Tidak terdapat pengaruh prestasi belajar ekonomi terhadap perilaku anti korupsi; dan 6) Terdapat pengaruh positif dan signifikan lingkungan keluarga terhadap perilaku anti korupsi dengan nilai Standardized Regression Weights sebesar 0,187 dan nilai C.R. sebesar 2,052 serta nilai $\mathrm{P}$ sebesar 0,02 atau kurang dari 0,05 $(\mathrm{P}<0,05)$.

Dari temuan-temuan tersebut maka baik orangtua siswa hendaknya menciptakan suasana lingkungan keluarga yang baik dan kondusif, dengan keteladanan yang baik, relasi antar anggota keluarga yang harmonis, keadaan ekonomi keluarga yang baik dan perhatian orang tua yang penuh. Bagi pihak keluarga hendaknya menanamkan nilai - nilai kejujuran, disiplin, 
tanggungjawab, dan sederhana serta rasa percaya pada kemampuan yang dimiliki oleh dirinya sendiri. Dan bagi guru ekonomi hendaknya meningkatkan prestasi belajar ekonomi dengan metode belajar yang menarik, media yang bagus dan sumber belajar yang beragam. Guru juga hendaknya menguatkan siswa agar percaya dengan kemampuan yang dimiliki oleh siswa dan mengimplementasikan nilai - nilai anti korupi dalam pembelajaran.

\section{DAFTAR PUSTAKA}

Aziz, S. (2015). Pendidikan Keluarga. Yogyakarta: Gava Media.

Bandura, A. (1997). Self Efficacy The Exercise of Control. New York: W.H Freeman and Company.

Haris, R. (2016). Pengaruh Efikasi diri dan Fasilitas Belajar terhadap Prestasi Belajar Siswa Program Keahlian Pemasaran SMK Negeri 1 Sukoharjo Tahun Ajaran 2015/2016.UNS.Skripsi.Tidak diterbitkan.

Kemendikbud. (2016). Peraturan Menteri Pendidikan No 24 Tahun 2016, Tentang KI dan KD Pelajaran pada Kurikulum 2013 pada Pendidikan Dasar dan Pendidikan Menengah

Kementerian Pendidikan dan Kebudayaan. (2011). Pendidikan Anti Korupsi Untuk Perguruan Tinggi. Kementerian Pendidikan dan Kebudayaan RI. Jakarta.

Ormrod, J. E. (2008). Psikologi Pendidikan Edisi Keenam Jilid 2. Alih bahasa: Amitya Kumara. Jakarta: Penerbit Erlangga.

Purwanti, A. (2011). Pengaruh Status Sosial Ekonomi Orang Tua, Persepsi atas Lingkungan, dan Prestasi Belajar Ekonomi terhadap Perilaku Konsumsi. Jurnal Ekonomi Bisnis,TH.16. No. 1, Diakses tanggal 23 Maret 2018 dari http://fe.um.ac.id/wp-content/uploads/2009/10/2-AnaPurwati.pdf

Purwanto, A. (2014). Pengaruh Efikasi Diri Terhadap Perilaku Menyontek Siswa Kelas V Sekolah Dasar Negeri Se-Gugus II Kecamatan Pakem Kabupaten Sleman Tahun Ajaran 2014/2015. Skripsi.Yogyakarta:Universitas Negeri Yogyakarta.

Rekapitulasi Tindak Pidana Korupsi. (31 Desember 2017) Diakses tanggal 9 Febuari 2018 dari https://acch.kpk.go.id/id/statistik/tindak-pidana-korupsi

Slameto. (2015). Belajar dan Faktor - Faktor yang Mempengaruhinya (Rev. ed). Jakarta: Rineka Cipta.

Subdirektorat Statistik Politik dan Keamanan. (2017).Indeks Perilaku anti Korupsi (IPAK) 2017.Jakarta: Badan Pusat Statistik.

Utami, M. N., Hasanah. \& Tarma. (2016). Pengaruh Pendidikan Karakter Anti Korupsi dalam Keluarga terhadap Perilaku Korupsi pada Remaja. Prodi Pendidikan Kesejahteraan Keluarga. FT UNJ. Jurnal Kesejahteraan Keluarga dan Pendidikan [JKKP] Vol.03 No.01.

Widanarti, N. \& Indati, A. (2002). Hubungan antara Dukungan Sosial Keluarga dengan Self Efficacy pada Remaja di SMU Negeri 9 Yogyakarta. UGM. Jurnal Psikologi No 2112 - 123 Diakses tanggal 23 Maret 2018 dari https://jurnal.ugm.ac.id/jpsi/article/view/7019

Yana, N.\&Nurjanah, N. (2014). Pengaruh Lingkungan Keluarga dan Lingkungan Sekolah terhadap Prestasi Belajar Ekonomi Siswa pada Mata Pelajaran Ekonomi di Kelas XI IPS SMA Negeri 1 Ciledug Kabupaten Cirebon. Edunomic Volume 2 No 1 Tahun 2014 